\title{
College Student Personality Traits Related to TOEIC and GEPT
}

\section{CHIA-HUI LIN}

Toko University

\author{
Bio Data: \\ Chia-Hui Lin was born in Taiwan and currently works at Toko \\ University.
}

\begin{abstract}
Personality had been conceptualized from different theoretical perspectives. Many psychologists had divided language of personality as important and useful for daily interaction. Thus, personality traits seemed to be an important factor in achieving educational goals for students learning foreign languages. TOEIC and GEPT tests measured English proficiency for the international working environment and educational organizations. A number of colleges and universities also employed TOEIC and GEPT tests as tools for student placement, tracking progress, and program evaluation. This study quantitatively examined non-experimental relationships among personality traits, TOEIC, GEPT, foreign language classroom anxiety, classroom structure, and satisfaction. A total of 110 surveys were distributed, and 100 surveys were returned, with a return rate of $91 \%$, with $9 \%$ missing data. Results showed that 3 of the 5 examined personality traits were statistically significant. Furthermore, TOEIC and GEPT tests did not influence personality traits, and GEPT participation had more statistical significance than TOEIC participation for student personality traits. The findings did not help statistical differences in foreign language classroom anxiety, and classroom structures for satisfaction and personality traits. The results of this research might influence educational organizations, government, and company decisions and strategies. Future studies should be enlarged to strengthen the generalizability of this research.
\end{abstract}

Keywords: personality traits, TOEIC, GEPT, foreign language classroom anxiety, classroom structure, and satisfaction.

\section{Introduction}

Personality has been conceptualized from different theoretical perspectives (John, Hampson, \& Goldberg, 1991; McAdams, 1995). Personality theory assumes that everyone is different and that people are uniquely characterized. Personality has been studied in various manners pertaining to different forms of processing and learning styles (Sharp, 2008). Many psychologists (Klages, 1926; Baumgarten, 1933; Allport \& Odbert, 1936) have divided language of personality as important and 
useful for daily interaction. Thus, personality traits seem to be an important factor in achieving educational goals for students learning foreign languages (Erton, 2010).

The Educational Testing Service (ETS) developed the Test of English for International Communication (TOEIC) in 1979 in Japan to improve international business and trade (ETS, 2008). Nearly 5 million people took the TOEIC in 2009, which is recognized by thousands of corporations as a measure of employee English proficiency (Yasuo, 2009). Another common test in Taiwan is the General English Proficiency Test (GEPT), which was developed in 1999 and commissioned by the Ministry of Education (MOE) in Taiwan. The Taiwan MOE encourages Taiwanese English proficiency (Roever \& Pan, 2008). To date, approximately 2.7 million examinees have registered for all levels of the GEPT (Mouth of World, 2010). Primary schools and numerous colleges require students to take the GEPT in Taiwan (Pan, 2009). The TOEIC and GEPT now play an important role in Taiwanese society, with English learning focusing more on communication skills. The TOEIC and GEPT are thus critical to the development of performance effectiveness on the global stage (Public Relationship Department, 2005).

In addition to the relationship between personality and the TOEIC or GEPT, the purpose of this research is to investigate the relationship between college students' personality traits and how students having different personality traits may affect foreign language classroom anxiety, classroom structure, and satisfaction.

\section{Literature Review and Hypothesis Development}

\section{Personality Traits}

Allport (1961) defined "Personality is a dynamic organization, inside the person, of psychophysical systems that create the person's characteristic patterns of behavior, thoughts and feelings." A personality factors model was also published by Fiske (1949). During the 1960s and 1990s, many researchers (Tupes \& Christal, 1961; Norman, 1963; Goldberg, 1993; Digman, 1996; John, Angleitner, \& Ostendorf, 1988; McCrae, 1992) combined and supported the five factors.

The five factor model is commonly measured by Costa and McCrae (1992) who developed the NEO-PI-R personality traits inventory, which includes five factors: Neuroticism; Extraversion; Openness; Agreeableness; and Conscientiousness. Table 1 and Fig. 1 show trait facets associated with the five domains of the five-factor model of personality. 
Table 1

Trait Facets Associated with the Five Domain Model of Personality

\begin{tabular}{ll}
\hline Neuroticism: & $\begin{array}{l}\text { Anxiety, hostility, depression, self-consciousness, } \\
\text { impulsiveness, vulnerability }\end{array}$ \\
\hline Extraversion: & $\begin{array}{l}\text { Warmth, gregariousness, assertiveness, activity, } \\
\text { excitement-seeking, positive emotions }\end{array}$ \\
Openness: & $\begin{array}{l}\text { Fantasy, aesthetics, feelings, actions, ideas, values } \\
\text { Trust, straightforwardness, altruism, compliance, } \\
\text { Agreeableness: }\end{array}$ \\
$\begin{array}{l}\text { modesty, tender-mindedness } \\
\text { Conscientiousness: }\end{array}$ & $\begin{array}{l}\text { Competence, order, dutifulness, achievement striving, } \\
\text { self-discipline, deliberation }\end{array}$ \\
\hline
\end{tabular}

Adopted from "Personality Traits" by Matthews and Deary (1998), Cambridge, University Press.

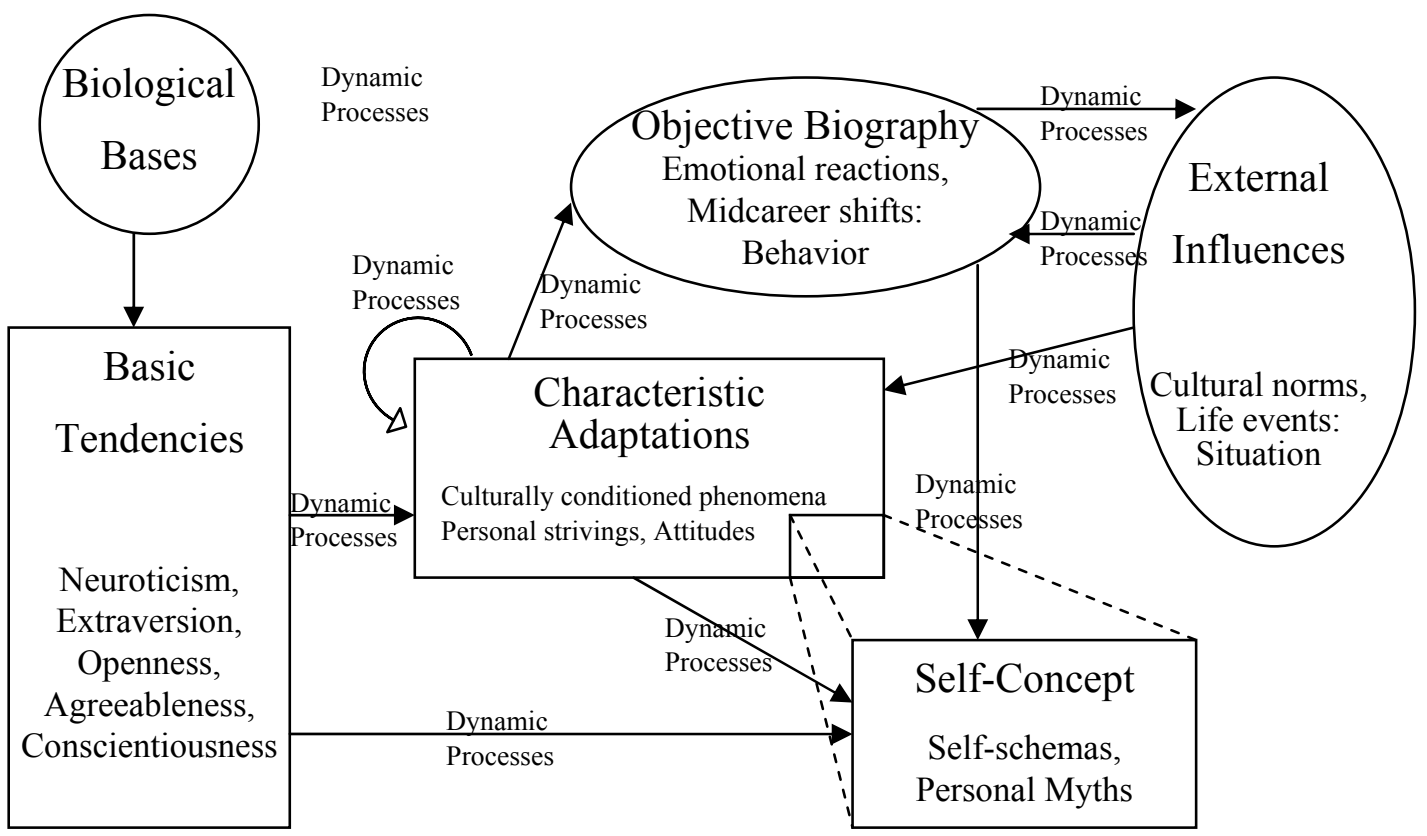

Figure 1. Operation of the FFT personality system. Adapted from "Personality in Adulthood" by McCrae and Costa $(1996,2003), 2^{\text {nd }}$ Edition, New York: Guilford Press.

A number of studies have examined the effects of personality traits for students' satisfaction from academic achievement in second language learning (Kiany, 1998; Bratko, Chamorro-Premuzic, \& Saks, 2006). Personality is an important factor that provides a framework of individual description and individuality. Personality can predict the likelihood of future academic success or failure (Duff, Boyle, Dunleavy, \& Ferguson, 2004; Laidra, Pullmann, \& Allik, 2006).

Extroversion Preferences: "Directing energy mainly toward the outer world of people and objects" (Myers, et el., 1998, p. 6). The opposite of introversion (Jung, 1923). Introversion Preference: "Directing energy mainly toward the inner world of experience and ideas" (Myers, et el., 1998, p. 6). According to personality type 
classification developed by Eysenck (1990), extraverted and introverted person engaged in emotional face processing were found to show differential cortical activations (Fink, 2005).

\section{TOEIC and GEPT}

Alderson and Wall (1993) stated that "tests are held to be powerful determiners of what happens in the classroom" (p.15). Tests such as the TOEIC and GEPT are major determiners of course curricula in Taiwan, where they are used as a graduation threshold for English language learning (Pan, 2009). The TOEIC is also commonly used in Japan as a benchmark of English proficiency when applying for employment (Sinharay et al., 2009). A large number of schools use the TOEIC to place students into English language levels and to evaluate program effectiveness (McNanara, 2000). The TOEIC is a registered trademark that concentrates on English for business purposes, and the test demonstrates how well employees speak and understand English (Lougheed, 2003).

The GEPT measures listening, reading, writing, and speaking skills on five levels: Elementary, Intermediate, High-Intermediate, Advanced, and Superior. Testtakers must pass the first stage of Listening and Reading sections before proceeding to the second stage of Writing and Speaking, prior to receiving GEPT certificates (Roever \& Pan, 2008). However, many college students experience classroom anxiety and fear because of answering and practicing answers in English during class (Chuang, 2010).

\section{Foreign Language Classroom Anxiety}

According to Horwitz, Horwitz, and Cope (1986), foreign language anxiety is "as a distant complex of self-perceptions, beliefs, feelings, and behaviors related to classroom language learning arising from the uniqueness of the language learning process also differs from general communication anxiety" (p.128). Other research (Chan \& Wu, 2004; Crookal \& Oxford, 1991) showed that anxiety can impede language learners' productivity and achievement. Horwitz, Horwitz, and Cope (1986) identified three anxieties related to communication: (1) apprehension (fear of communicating with others); (2) test anxiety (fear of examinations and assignments evaluating student performance); and (3) fear of negative evaluation (concern with how other people view the speakers) as having an influence on language learning.

\section{Classroom Structure}

Liu and Jackson (2008) identified a significant correlation between language anxiety in the classroom and language proficiency. The SPECSS structures define authority, task, grouping, reward, evaluation, and time structures as the basic building blocks of classroom and school organizations (Epstein, 1988). Squires, Huitt, and Segars $(1981,1983)$ proposed a model for improving classroom and school effectiveness and effecting change in educational fields. Individual perception toward the environment influences learner needs. Therefore, the classroom environment affects learners' behavioral, affective, and cognitive patterns (Pintrich \& Schunk, 2002). 


\section{Student Satisfaction}

Satisfaction is defined as the "the state of a person whose performance (or outcome) has fulfilled his or her expectations. Experiences of success provide students with more power to achieve their goals (Ebata, 2008). Satisfaction is thus a function of relative levels of expectation and perceived performance" (Hom, 2002, p.6). Language learner satisfaction can result in language learning (Beltyukova \& Fox, 2002). To experience students' learning language success with satisfaction in the classroom, it is essential to provide a relaxing learning environment that contains various materials and activities. Gradually, the classroom becomes more challenging and effective for students to achieve satisfaction (Ebata, 2008).

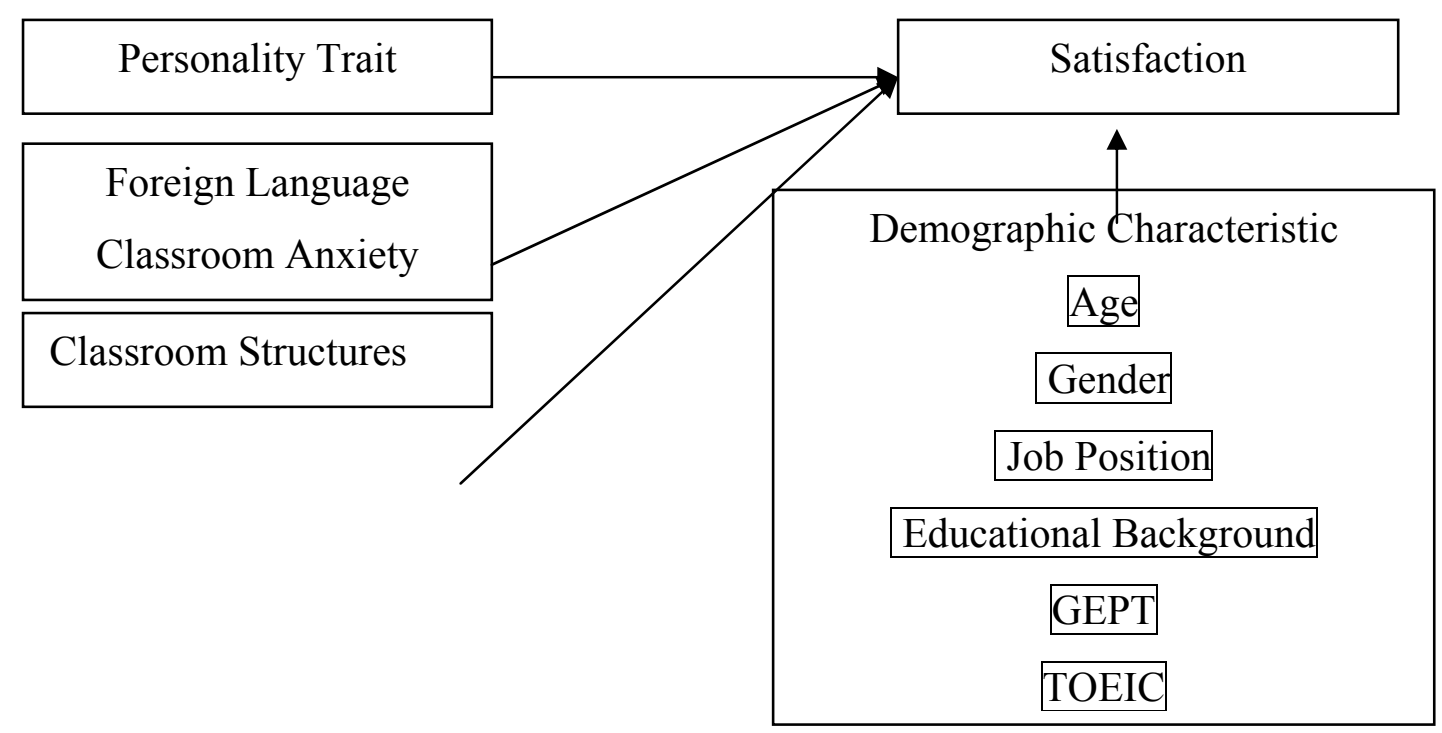

Figure 2. Theoretical framework

\section{Hypotheses}

H1: The TOEIC and GEPT have statistical significance for personality traits.

H2: The TOEIC has more statistical significance than the GEPT for personality traits. H3: Student satisfaction (interaction, structure, and support) has statistically significant explanatory variables of perceived personality traits (conscientiousness, extraversion, agreeableness, openness, and neuroticism).

H3a: Student satisfaction (interaction, structure, and support) has statistically significant explanatory variables of perceived personality traits with conscientiousness.

$\mathrm{H} 3 \mathrm{~b}$ : Student satisfaction (interaction, structure, and support) has statistically significant explanatory variables of perceived personality traits with extraversion.

H3c: Student satisfaction (interaction, structure, and support) has statistically significant explanatory variables of perceived personality traits with agreeableness.

H3d: Student satisfaction (interaction, structure, and support) has statistically significant explanatory variables of perceived personality traits with openness.

H3e: Student satisfaction (interaction, structure, and support) has statistically significant explanatory variables of perceived personality traits with neuroticism. 
H4: Foreign language classroom anxiety and classroom structures have statistically significant explanatory variables for satisfaction (interaction, structure, and support) and personality traits (conscientiousness, extraversion, agreeableness, openness, and neuroticism).

\section{Research Methodology}

\section{Research Design}

The research design in this study used non-experimental, quantitative, SPSS 17.0 multiple regression analysis, ANOVA, two-way ANOVA, and MANOVA to explore the relationship of personality traits, foreign language classroom anxiety scales, classroom structure, and satisfaction. The five questionnaires included (1) Background Demographic Characteristics developed by the researchers, (2) personality traits measurement by items from NEO-PI-R developed by Costa and McCrae (1992), (3) foreign language classroom anxiety measurements by items from the Foreign Language Classroom Anxiety Scale (FLCAS) developed by Horwitz, Horwitz, and Cope (1986), (4) classroom structure measurements by items from Students' Perceptions of Classroom Structure Scale (SPECSS) developed by Church, Elliot, and Gable (2001), and (5) satisfaction measurements by items from Course Interaction, Structure, and Support (CISS) developed by Johnson, Shaik, and Palma-Rivas (2000).

The Background Demographic Characteristics are age, gender, work-related questions, educational level, GEPT test-taking experience, and TOEIC test-taking experience. The NEO-PI-R explores five factors: (a) Neuroticism, (b) Extraversion, (c) Openness, (d) Agreeableness, and (e) Conscientiousness. The SPECSS explores six factors: (a) task, (b) authority, (c) reward, (d) grouping, (e) evaluation, and (f) time. The CISS consists of three subscales: (a) interaction, (b) structure, and (c) support. The study used 110 responses randomly selected from college students in Taiwan. The design focused on quantitative methods with close-ended questions on the survey.

\section{Population and Sampling Plan}

Target population. According to the Taiwan Ministry of Education Department of Statistics (2010), nine colleges and universities are in Taichung City and County, and three colleges and universities are in Chiayi City and County. Target populations were 110 college students in Taiwan. The students' age of 18 to 41 were tested, students' parents educational background from middle school to $\mathrm{PhD}$ were also tested in the study.

Accessible population. The convenience sample included students enrolled in Asia University and Toko University. Asia University is a newly established private school in Taichung County, and is recognized for research and teaching in health care, computer science, and management. ToKo University was established in 2001, and became a practical university in 2010. 
Sampling plan. The entire accessible population was invited to participate in the study. However, the final data-producing sample was self-selected depending on those who agreed to participate in the study.

\section{Instrumentation}

The study survey consisted of five parts: (1) Background Demographic Characteristics, developed by the researchers, (2) NEO-PI-R, developed by Costa and McCrae (1992), (3) Foreign Language Classroom Anxiety Scale (FLCAS), developed by Horwitz, Horwitz, and Cope (1986), (4) Students' Perceptions of Classroom Structure Scale (SPECSS), developed by Church, Elliot, and Gable (2001), and (5) Course Interaction, Structure, and Support (CISS), developed by Johnson, Shaik, and Palma-Rivas (2000).

\section{Results}

This study examined relationships among TOEIC, GEPT, foreign language classroom anxiety, perceptions of classroom structures, satisfaction, and personality trait variables. Of the 110 surveys, 100 were returned, with a return rate of $91 \%$ and missing data of $9 \%$.

\section{Hypotheses}

H1: TOEIC and GEPT had no statistical significance for personality traits, $p=.114>$

.05. Hypothesis 1 was not supported.

Table 2

ANOVA Analysis of TOEIC, GEPT and Personality Traits

\begin{tabular}{|c|c|c|c|c|c|}
\hline Source & $\begin{array}{l}\text { Type III Sum } \\
\text { of Squares }\end{array}$ & $\mathrm{df}$ & Mean Square & $\mathrm{F}$ & Sig. \\
\hline Intercept & 162.822 & 1 & 162.822 & 734.339 & .000 \\
\hline GEPT * TOEIC & 1.362 & 3 & .454 & 2.047 & .114 \\
\hline Error & 17.738 & 80 & .222 & & \\
\hline Total & 1055.000 & 90 & & & \\
\hline Corrected Total & 21.389 & 89 & & & \\
\hline
\end{tabular}

a. R Squared $=.171($ Adjusted $\mathrm{R}$ Squared $=.077)$

$\mathrm{H} 2$ : Table 2 shows that the $R$ Square value of the model accounted for $4.2 \%$ of the variation in TOEIC and personality traits, and 7.1\% with GEPT and personality traits. Research Hypothesis 2 was not supported.

Table 3

Multiple Regression R Square Analyses of TOEIC, GEOT, and Personality Traits

\begin{tabular}{|c|c|c|c|c|c|}
\hline & Model & $R$ & $R$ Square & $\begin{array}{l}\text { Adjusted } \\
R \text { Square }\end{array}$ & $\begin{array}{l}\text { Std. Error of the } \\
\text { Estimate }\end{array}$ \\
\hline TOEIC & 1 & $.204(a)$ & .042 & .031 & .483 \\
\hline GEPT & 2 & $.266(a)$ & .071 & .060 & .475 \\
\hline
\end{tabular}

H3a: There was statistical significance with satisfaction (interaction, structure, and support) and personality traits with conscientiousness, $p=.032<.05$. 
Table 4

ANOVA of Satisfaction and Personality Traits with Conscientiousness

\begin{tabular}{|c|c|c|c|c|c|c|}
\hline Model & & Sum of Squares & $\mathrm{df}$ & Mean Square & $\mathrm{F}$ & Sig. \\
\hline \multirow[t]{3}{*}{1} & Regression & 4.221 & 3 & 1.407 & 3.076 & $.032^{\mathrm{a}}$ \\
\hline & Residual & 39.335 & 86 & .457 & & \\
\hline & Total & 43.556 & 89 & & & \\
\hline
\end{tabular}

a. Predictors: (Constant), SupportAVG, InteractionAVG, StructureAVG

b. Dependent Variable: ConscientiousnessAVG

$\mathrm{H} 3 \mathrm{~b}$ : There was statistical significance with satisfaction (interaction, structure, support) and personality traits with extraversion, $p=.004<.05$.

Table 5

ANOVA of Satisfaction and Personality Traits with Extraversion

\begin{tabular}{|c|c|c|c|c|c|c|}
\hline Model & & Sum of Squares & $\mathrm{df}$ & Mean Square & $\mathrm{F}$ & Sig. \\
\hline \multirow{3}{*}{1} & Regression & 5.253 & 3 & 1.751 & 4.720 & $.004^{\mathrm{a}}$ \\
\hline & Residual & 31.903 & 86 & .371 & & \\
\hline & Total & 37.156 & 89 & & & \\
\hline
\end{tabular}

a. Predictors: (Constant), SupportAVG, InteractionAVG, StructureAVG

b. Dependent Variable: ExtraversionAVG

H3c: There was statistical significance with satisfaction (interaction, structure, support) and personality traits with agreeableness, $p=.006<.05$.

Table 6

ANOVA of Satisfaction and Personality Traits with Agreeableness

\begin{tabular}{|c|c|c|c|c|c|c|}
\hline Model & & Sum of Squares & $\mathrm{df}$ & Mean Square & $\mathrm{F}$ & Sig. \\
\hline \multirow[t]{3}{*}{1} & Regression & 3.475 & 3 & 1.158 & 4.465 & $.006^{\mathrm{a}}$ \\
\hline & Residual & 22.313 & 86 & .259 & & \\
\hline & Total & 25.789 & 89 & & & \\
\hline
\end{tabular}

a. Predictors: (Constant), SupportAVG, InteractionAVG, StructureAVG

b. Dependent Variable: AgreeablenessAVG

H3d: There was no statistical significance with satisfaction (interaction, structure, and support) and personality traits with openness, $p=.117>.05$. 
Table 7

ANOVA of Satisfaction and Personality Traits with Openness

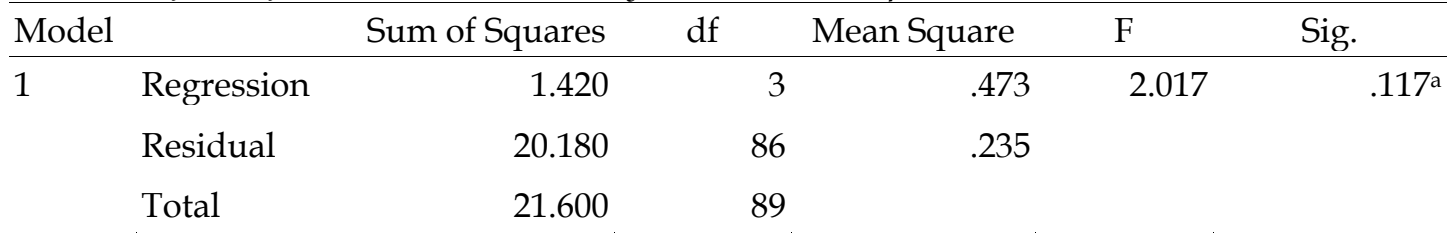

a. Predictors: (Constant), SupportAVG, InteractionAVG, StructureAVG

b. Dependent Variable: OpennessAVG

H3e: There was no statistical significance with satisfaction (interaction, structure, and support) and personality traits with neuroticism, $p=.352>.05$

Table 8

ANOVA of Satisfaction and Personality Traits with Neuroticism

\begin{tabular}{|c|c|c|c|c|c|c|}
\hline \multirow{3}{*}{$\begin{array}{l}\text { Model } \\
1\end{array}$} & & Sum of Squares & $\mathrm{df}$ & Mean Square & $\mathrm{F}$ & Sig. \\
\hline & Regression & 3.955 & 3 & 1.318 & 1.104 & $.352^{\mathrm{a}}$ \\
\hline & Residual & 102.668 & 86 & 1.194 & & \\
\hline & Total & 106.622 & 89 & & & \\
\hline
\end{tabular}

a. Predictors: (Constant), SupportAVG, InteractionAVG, StructureAVG

b. Dependent Variable: NeuroticismAVG

H4: There was no statistical difference in foreign language classroom anxiety, and classroom structures for satisfaction and personality traits.

Table 9

MANOVA of Foreign Language Classroom Anxiety, and Classroom Structures for Satisfaction and Personality Traits

\begin{tabular}{lcccccc}
\hline Variables & df & \multicolumn{1}{c}{ SSCP } & Value & $\begin{array}{c}\text { F Value } \\
\text { Personality } \\
\text { Trait }\end{array}$ & $\begin{array}{c}\text { F Value } \\
\text { Satisfaction }\end{array}$ & Sig. \\
\hline FLCAS & 2 & {$[.019 .003]$} & .876 & & .962 \\
& & {$[.003 .2 .865]$} & & & .008 \\
Classroom & 3 & {$[.5741 .270]$} & .873 & & .512 \\
$\begin{array}{l}\text { Structure } \\
\text { FLCAS* }\end{array}$ & 2 & {$[1.2703 .202]$} & & & .103 \\
Classroom & & {$[.274 .083]$} & .897 & $.553^{* *}$ & $3.490^{* * *}$ & .577 \\
$\begin{array}{l}\text { Structure } \\
\text { Error }\end{array}$ & 82 & {$[20.3027 .148]$} & & & & .035 \\
& & {$[7.14822 .991]$} & & & & \\
\hline
\end{tabular}

\section{Reliability Analysis}

To estimate the reliability of foreign language classroom anxiety, classroom structures, satisfaction, and personality traits, Cronbach's alphas and item analyses were conducted on all variables: alphas $=.613$. 
Table 10

Cronbach's Alpha Coefficients of Foreign Language Classroom Anxiety, Classroom Structures, Satisfaction, and Personality Traits

\begin{tabular}{lrrrr} 
Cronbach's Alpha & \multicolumn{2}{c}{$\begin{array}{c}\text { Cronbach's Alpha Based on } \\
\text { Standardized Items }\end{array}$} & N of Items & \\
\hline & .613 & & .618 & 11 \\
\hline
\end{tabular}

\section{Conclusion}

Personality is a critical psychological mechanism leading a person's behavior to satisfaction (Kwon \& Song, 2011). Personality was examined to understand students' foreign language anxiety, classroom structures, and satisfaction from this study.

This research shows that the personality traits conscientiousness, extraversion, and agreeableness influence student satisfaction. However, this study uncovered the personality traits openness and neuroticism. Furthermore, the TOEIC and GEPT do not influence personality traits, and the GEPT has more statistical significance than the TOEIC for student personality traits. The finding does not help statistical difference in foreign language classroom anxiety and classroom structures for satisfaction and personality traits.

\section{Practical Implications}

The Taiwan MOE is focused on improving English ability. The TOEIC and GEPT are two tests of language learning effectiveness to present and prove Taiwanese English ability in society. The research findings are important to educational organizations, the Taiwanese government, companies, TOEIC and GEPT test-takers, and researchers. The results may influence educational organizations, government, and company decisions and strategies. Other researchers can benefit by duplicating or modifying this study. The Taiwanese government or companies could support more funding to all Taiwanese schools to enhance the quality of the TOEIC and GEPT.

\section{Limitations}

This study has limitations. First, the number of participants was too small to compare with the 5 million test takers of the TOEIC and GEPT per year worldwide. Furthermore, the respondents might also be biased to answer the questions because of the small number of participants in the colleges. Finally, the estimated time for completing this survey was ten minutes, and the participants may have been impatient and may not have answered the questions carefully and accurately.

\section{Recommendations for Future Study}

Future studies might adopt a qualitative design by interviewing participants and eliciting respondents' opinions. Future studies should explore more factors and include other cultures or countries to explore the difference between TOEIC and GEPT for personality traits. Future studies should also use Multidimensional Scaling (MDS) and AMOS 18.0 to facilitate data reading and to test more dependent variables. The accessible population should also be enlarged to strengthen the generalizability of the study. 


\section{Acknowledgements}

Thanks to my whole family who always support me to do my favorite academic jobs and do feel free to do the research. 


\section{References}

Alderson, C., \& Wall, D. (1993). Does washback exist? Applied Linguistics, 14, 115-129. Allport, G. W. (1961). Pattern and growth in personality. New York: Holt.

Allport, G. W., \& Odbert, H. S. (1936). Trait-names: A psycho-lexical study. Psychological Monographs, 47(211).

Baumgarten, F. (1933). 'Die Charktereigenschaften'. [The character traits]. In Beitraege zur Charakter- und Persoenlichkeitsforschung (Whole No. 1). Bern, Switzerland:

A. Francke.

Beltyukova, S. A., \& Fox, C. M. (2002). Student satisfaction as a measure of student development: Towards a universal metric. Journal of College Student Development, 43(2), 161-172.

Bratko, D., Chamorro-Premuzic, T., \& Saks, Z. (2006). Personality and social performance: Incremental validity of self- and peer-rating over intelligence. Personality and Individual Difference, 41, 131-142.

Carrol, J. B. (1963). A model for school learning. Teacher College Record, 64(2), 723-733.

Chan, Y. U., \& Wu, G. C. (2004). A study of foreign language anxiety of EFL elementary school students in Taipei county. Journal of National Taipei Teacher College, 17(2), 287-320.

Church, A. A., Elliot, A. J., \& Gable, S. L. (2001). Perceptions of classroom environment, achievement goals, and achievement outcomes. Journal of Educational Psychology, 93(1), 43-54.

Costa, P. T., \& McCrae, R. R. (1992). Revised NEO Personality Inventory (NEO-PI-R) and NEO Five-Factor Inventory (NEO-FFI) professional manual. Odessa, FL: Psychological Assessment Resources.

Crookal, D., \& Oxford, R. (1991). Dealing with anxiety: Some practical activities for language learners and teacher trainees. Englewood Cliffs, NJ: Prentice Hall.

Digman, J. M. (1996). The curious history of the five factor model. In J. Wiggens (Ed.), The Five Factor Model of Personality. New York: Guilford Press.

Duff, A., Boyle, E., Dunleavy, K., \& Ferguson, J. (2004). The relationship between personality, approach to learning and academic performance. Personality and Individual Difference, 36, 1907-1920.

Ebata, M. (2008). Motivation factors in language learning. The Internet TESL Journal, $8(4)$.

Educational Testing Service. (2008). TOEIC examine handbook-listening $\mathcal{E}$ reading. Princeton, NY: Educational Testing Service.

Epstein, J. L. (1988). Effective schools or effective students: Dealing with diversity. In Haskins, \& D. MacRae (Eds.), Polices for American's public schools: Teacher, equator, and indicator (pp. 89-126). Norwood,NJ: Albex.

Erton, I. (2010). Relations between personality traits, language learning styles and success in foreign language achievement. Journal of Education, 38, 115-126.

Eysenck, H. J. (1990). Biological bases of personality. In L. A. Pervin (Ed.), Handbook of personality: Theory and research (pp. 244-276). Guilford press: New York.

Fink, A. (2005). Event-related desynchronization in the EEG during emotional and cognitive information processing: differential effects of extraversion. Biol. Psychol, 70, 152-160. 
Fiske, D. W. (1949). Consistency of the factorial structures of personality ratings from different sources. Journal of Abnormal Social Psychology, 44, 329-344.

Goldberg, L. R. (1993). The structure of phenotypic personality traits. American Psychologist, 48(1), 26-34.

Hom, W. (2002). Applying customer satisfaction theory to community college planning of students services. IJournal, 2(1), 21-35.

Horwitz, E. K., Horwitz, M. B., \& Cope, J. (1986). Foreign language classroom anxiety. Modern Language Journal, 70, 125-132.

John, O. P., Angleitner, A., \& Ostendorf, F. (1988). The lexical approach to personality: A historical review of trait taxonomic research. European Journal of Personality, 2, 171-203.

Johnson, S. D., Aragon, S. R., Shaik, N., \& Palma-Rivas, N. (2000). Comparative analysis of learner satisfaction and learning outcomes in online and face-to face learning environments. JI of Interactive Learning Research, 11(1), 29-49. Retrieved from ProQuest database.

John, O. P., Hampson, S. E., \& Goldberg, L. R. (1991). Is there a basic level of personality description? Journal of Personality and Social Psychology, 60, 348-361.

Jung, C. G. (1923). Psychological types. Great Britain: Pantheon Books.

Kiany, G. R. (1998). English proficiency \& academic achievement in relation to extraversion-introversion: A preliminary study. International Journal of Applied Linguistics, 8(1), 113-130.

Klages, L. (1926). The science of character. London: Allen and Unwin.

Kwon, N., \& Song, H. (2011). Personality traits, gender, and information competency among college students. Malaysia Journal of Library $\mathcal{E}$ Information Science, 16(1), 87-107.

Laidra, K., Pullmann, H., \& Allik, J. (2006). Personality and intelligence as predicators of academic achievement: A cross-sectional study from elementary to secondary school. Personality and Individual Difference, 42(3), 441-451.

Liu, M., \& Jackson, J. (2008). An exploration of Chinese EFL learners' unwillingness to communicate and foreign language anxiety. The Modern Language Journal, $92,71-86$

Lougheed, L. (2003). How to prepare for the TOEIC test (3rd ed.). Hauppauge, NY: Barron Educational Service.

Matthews, G., \& Deary, I. J. (1998). Personality traits. Cambridge: Cambridge. University Press.

McAdams, D. P. (1995). What do we know when we know a person? Journal of Personality, 63, 365-396.

McCrae, R. R., \& Costa, P. T. (1996). Toward a new generation of personality theories: Theoretical contexts for the five factor model. In J. Wiggens (Ed.), The five factor model of personality. New York: Guilford Press.

McNamara, T. (2000). Language testing. Oxford: Oxford University Press.

Myers, I. B., McCaulley, M. H., Quenk, N. L., \& Hammer, A. L. (1998). MBTI manual: A guide to the development and use of the Myers-Briggs type indicator. PaloAlto, CA: Consulting Psychologists Press. 
Norman, W. T. (1963). Toward an adequate taxonomy of personality attributes: Replicated factor structure in peer nomination personality ratings. Journal of Abnormal and Social Psychology, 66, 574-583

Pan, Y. C. (2009). The impact of test design on teaching. The International Journal of Educational and Psychological Assessment, 3, 94-103.

Pintrich, P. R., \& Schunk, D. H. (Eds.). (2002). The role of goals and goal orientation. Motivation in Education: Theory, Research, and Applicants, 2, 190-242. London: Pearson Education.

Public Relation Department. (2005). TOEIC in action around the globe. Retrieved from www.toeic.or.jp/toeic_en/pdf/newsletter/newsletterdigest89.pdf

Rover, C., \& Pan, Y. C. (2008). GEPT: General English Proficiency Test. Language Testing, 25(3), 403-418. Retrieved from ProQuest database.

Sinharay, S., Powers, D. E., Feng, Y., Saldivia, L., Giunta, A., Simpson, A., \& Weng, V. (2009). Appropriateness of the TOEIC bridge test for three students in three countries of south America. Language Testing, 26(4), 589-619. Retrieved from ProQuest database.

Sharp, A. (2008). Personality and second language learning. Asian Social Science, 4(11), 17-25. Retrieved from ProQuest database.

Squire, D., Huitt, W., \& Segars, J. (1981). Improving classroom and school: What's important. Educational Leadership, 39(3), 174-179.

Tupes, E. C., \& Christal, R. E. (1961). Recurrent personality factors based on trait ratings. Lackland Air Force Base, TX: Aeronautical Systems Division, Personnel Laboratory.

Yasuo, K. (2009). The TOEIC program celebrates 30 years of measuring global workplace English; test that began with 3,000 test takers now administers more than 5 million tests per Year. Marketwire, Toronto. 